\title{
Mariana de Neoburgo en Toledo
}

\author{
Ángel SANTOS VAQUero \\ Doctor en Historia \\ ansava@wanadoo.es
}

Recibido: 10 de febrero de 2010

Aceptado: 16 de diciembre de 2010

\section{Resumen}

La muerte sin descendencia del rey Carlos II trajo como consecuencia la elección de Felipe V, nieto de Luis XIV de Francia, como nuevo monarca de España. Su llegada estuvo precedida del exilio de la reina viuda, doña Mariana de Neoburgo, a Toledo. La estancia de esta durante cinco años y medio en la ciudad Imperial, alteró la vida de sus instituciones (cabildo catedralicio y Ayuntamiento) y del pueblo tanto desde el punto de vista social como político y económico. Su incidencia positiva o negativa en el curso de la vida capitalina es lo que se trata de analizar en este artículo.

Palabras clave: Sucesión a la corona española (1700), exilio de la reina viuda, guerra, Ayuntamiento de Toledo, cabildo catedralicio, incidencias sociales, política y economía

\section{Maria Anna of Neuburg in Toledo}

\begin{abstract}
The death of the childless Charles II of Spain caused the election to the Spanish throne of Philip V, grandson of Louis XIV of France. His arrival to Spain was preceded by the exile to Toledo of the queen dowager Maria Anna of Neuburg. She lived in the city for five years and a half and this altered many aspects of its institutions (the Cathedral Chapter, the Toledo City Council) and of the inhabitants themselves. This paper examines both the positive and negative aspects in the social, political and economic impact of Maria Anna's exile in this city.
\end{abstract}

Key words: Succession to the Spanish crown (1700), exile of the widowed queen, war, City council of Toledo, cathedral chapter, social incidences, Politics and Economics

\section{Referencia normalizada}

Santos Vaquero, A. (2011). "Mariana de Neoburgo en Toledo". Cuadernos de Historia Moderna, Vol 36.: pp. 151-175

Sumario: Antecedentes. 1. Incidencia social y política. 2. Incidencia económica. Conclusión. 


\section{Antecedentes}

Maria Luisa de Orleáns, casada con Carlos II a finales del año 1679, murió de manera imprevista, como resultado de un accidente de equitación, en febrero de $1689^{1}$. Con gran prontitud (en un plazo de seis meses), con motivo de procurar un heredero al trono, se organizó el nuevo matrimonio del monarca con Mariana de Neoburgo, hija del Elector del Palatinado.

A lo largo del último decenio del siglo XVII se iba comprobando la incapacidad del rey para tener descendencia, proporcionando al reino uno de sus principales y más agudos problemas: la sucesión de la monarquía.

Se desarrollaron numerosas intrigas internacionales y las distintas facciones de fuera y dentro del reino comenzaron a efectuar movimientos para conseguir sus propósitos en cuanto a quién elevar al futuro trono vacante del reino de España. Mariana de Neoburgo ejercía una gran influencia en el rey y su posición alimentaba las esperanzas de una sucesión por parte de la rama de los Habsburgo ${ }^{2}$, llegándose a nombrar como heredero al trono de España al Príncipe Elector de Baviera, José Fernando, gracias al apoyo que la reina obtuvo del Arzobispo de Toledo, cardenal Portocarrero, y del conde de Oropesa. Pero la muerte de José Fernando de Baviera truncó los propósitos reales y la situación dio un vuelco en su contra al alzarse un fuerte grupo francófilo, encabezado por el cardenal Portocarrero - que había cambiado su postura-. Al final fue la voz preponderante del prelado, al que apoyaban casi todos los grandes de España y la mayor parte de la jerarquía eclesiástica, la que obtuvo el éxito al conseguir que el monarca nombrara en su testamento, firmado el 2 de octubre de 1700, como sucesor al trono de España al nieto del rey de Francia, Felipe, duque de Anjou. Nombramiento que se acogió con alivio en Madrid e inquietud en las chancillerías europeas.

La salud de Carlos empeoraba rápidamente y el 1 de noviembre de 1700 expiraba. La reina viuda no fue muy estimada ni en la corte española ni por las gentes de la Villa debido a su naturaleza intrigante, la imposibilidad de concebir un deseado heredero, su carácter altivo y dominante, rodearse de una ambiciosa camarilla alemana y derrochar el dinero hasta el punto de sacar ciertas cantidades del reino para enviarlo a Alemania.

Felipe V fue proclamado rey de España el 16 de noviembre de 1700; el 4 de diciembre partía para ocupar el trono y llegó a Madrid el 18 de febrero del siguiente año; pero con anterioridad, a instancias del rey francés Luis XIV a través de su embajador en España, Harcourt, instigación de la princesa de los Ursinos y presiones del cardenal Portocarrero, la reina viuda hubo de abandonar el alcázar madrileño y refugiarse en casa del duque de Terranova y de Monteleón (16-1-1701) ${ }^{3}$, su caballerizo

\footnotetext{
${ }^{1}$ KAMEN, Henry, Una sociedad conflictiva: España 1469-1714, Ediciones Altaya, Madrid, 1996, p. 417; la historiografía actual se inclina por una intoxicación alimentaria o una peritonitis.

${ }^{2}$ Para ello consiguió de su marido que nombrara a un hombre de su confianza, Francisco Moles, duque de Pareti, como embajador en la corte de Viena, al que dio instrucciones personalmente, ADALBERTO DE BAVIERA, Mariana de Neoburgo, Reina de España, Madrid, Espasa-Calpe,1938, p. 289.

${ }^{3}$ MARTÍNEZ LEIVA, G.:"Mariana de Neoburgo: cartas de un exilio", [Comunicación] Espacios
} 
mayor, único miembro de su Casa que permaneció fiel a su señora en momentos tan difíciles para ella; sin embargo, poco tiempo pudo disfrutar de la vida en un palacio de la capital del reino, pues el 2 de febrero era obligada a salir de Madrid-apremiada por el Cardenal, vejada y casi totalmente abandonada de sus criados ${ }^{4}$ - hacia Toledo -donde habría de residir más de cinco años y medio-, pues solicitó se le dejase residir lo más cerca posible de Madrid. ¿Por qué? ¿Porque quería permanecer cerca de la corte a fin de seguir influyendo en ella? ¿Porque pensaba que esta situación no duraría mucho y que volvería a palacio cuando tomara las riendas del reino el pretendiente austriaco? ¿Porque en Toledo siempre la habían tratado exquisitamente y se sentía querida y respetada en esta ciudad?

\section{Incidencia social y política}

El 27 de enero se recibió carta del Presidente de Castilla en el Ayuntamiento toledano indicando que la reina viuda iba a venir a Toledo, que enviaría personas a reconocer el estado en que se hallaba el alcázar para su residencia y que no se hicieran festejos ni demostraciones públicas de festivo recibimiento, pero que se la acogiera con el agrado, amor y fidelidad requeridos ${ }^{5}$ El Ayuntamiento de la ciudad hubo de realizar algunos gastos con motivo de la llegada y estancia de doña Mariana: reparación del camino de Madrid, allanamiento del espacio entre la Puerta de Bisagray la delCambrón, limpieza y empedrado de calles. En ello se gastó 1.078 rs. ${ }^{6}$ Además se recibieron órdenes de la Junta de Gobierno y de su Presidente para que se despejase y reparase el alcázar y se asistiese con 20.000 rs. de las rentas reales para dichos arreglos?

Llegó a la capital del Tajo el 4 de febrero, acompañada, entre otros, por el duque de Monteleón, su mayordomo mayor y Juan Tomás de Goyeneche, su tesorero, aunque se impidió que la asistiesen otros personajes afines a su persona, con el fin de mantenerla lo más aislada posible del poder y la corte. Fue recibida a su llegada a Toledo por el Ayuntamiento y se alojó en el Palacio Arzobispal mientras se acondicionaba el alcázar. El Ayuntamiento, además de nombrar caballeros que se ocuparan de acomodar y asistir a los personajes de la Casa de la reina, estableció el ceremonial de acogida. Cuando se tuvo noticia de que S.M. había llegado a Olías, salió el Corregidor, don Alonso Pacheco, conde de Ibangrande, caballero de la Orden de Alcántara, acompañado de cuatro caballeros y dos sofieles en un coche. En otro carruaje iban algunos otros caballeros de acompañamiento. Sobre las dos de la tarde

de poder: corte, ciudades y villas (s. XVI-XVIII), (Univ. Aut. de Madrid, octubre 2001). Madrid: Universidad Autónoma, 2002, p. 292 (vol. I)

${ }^{4}$ Dimitió su mayordomo mayor, Santiesteban, a quien acompañaron su hermana, la duquesa de Frías, camarera mayor de la reina y las mayoría de sus damas camaristas, PRÍNCIPE DE BAVIERA, A. y MAURA GAMAZO, G.: Documentos inéditos referentes a las postrimerías de la Casa de Austria en España, R.A.H, (Centro de Estudios Políticos y Constitucionales), Madrid, 2004, pp. 1375-76

${ }^{5}$ Archivo Municipal de Toledo (A.M.T.), libro de actas municipales de $1700, \mathrm{n}^{\circ} 121$, ayuntamiento de 27-1-1701

${ }^{6}$ A.M.T., libro de actas municipales de 1701, $\mathrm{n}^{\mathrm{o}}$ 122, ayuntamiento de 7-3-1701

${ }^{7}$ A.M.T, libro de actas municipales de $1700, \mathrm{n}^{\circ}$ 121, ayuntamiento de 2-2-1701 
(habían salido entre las 10 y las 11 horas) se apearon en la casa del jurado don Gabriel Alonso de Buendía. De allí salieron y marcharon a la casa donde posaba la reina, la cual ya había comido. Se pidió licencia al mayordomo mayor y la ciudad entró y se puso a sus pies. La reina participó a las autoridades que de ningún modo debían ir a caballo acompañándola, porque era mucho el camino a recorrer y porque deseaba entrar en Toledo de noche. La comitiva se apeó en la puerta del Palacio Arzobispal, donde S.M. descansaría, y la acompañaron hasta la real cámara, a la vez que se solicitaba día y hora para acudir toda la corporación municipal a besar su mano ${ }^{8}$.

El 5 de febrero el Corregidor expuso a los caballeros capitulares que todavía no se le había notificado qué día se haría el besamanos de la reina viuda, pero que el mayordomo de S.M., don Juan de Villavicencio, le había comunicado que como el salón donde la reina les había de recibir no era muy grande, se redujese el número de los que participaran. La ciudad acordó que acudieran doce caballeros regidores y seis jurados ${ }^{9}$.

Acondicionado el alcázar, doña Mariana pasó a ocuparle dejando el palacio arzobispal el sábado día 9 de abri ${ }^{10} \mathrm{y}$, organizada su Casa según el protocolo austriaco, invitó al nuevo rey de España a visitarla, para lo que le obsequió con una lujosa carroza que el año anterior le había regalado a su esposo el conde de Vaudemont, tirada por seis hermosos caballos que su hermano Juan Guillermo le había enviado ${ }^{11}$, quizás con la intención de congraciarse con el joven monarca y hacerse perdonar sus veleidades austracistas. El 6 de mayo, la ciudad acordó enviar una embajada a la reina viuda ofreciéndole a ella y a su familia los balcones del Ayuntamiento para presenciar la procesión del Corpus ${ }^{12}$ y el 11 de julio se envió dos regidores y dos jurados a visitarla con motivo de sus $\operatorname{santo}^{13}$. En la sesión de 30 de julio el Corregidor dio a conocer a los capitulares que había tenido noticia de que el rey Felipe V, acompañado por el cardenal Portocarrero, vendría a Toledo el 3 de agosto muy temprano, que primero haría oración ante la Virgen del Sagrario, en la catedral, después pasaría a visitar a la reina viuda y posteriormente bajaría a comer al Palacio Arzobispal y esa misma tarde partiría. Se dispuso revisar los caminos de la Puerta de Bisagra al alcázar y a la Puerta del Cambrón, reparar el empedrado del Hospital de Afuera, reconocer las calles que van de la Puerta del Cambrón al Ayuntamiento y que se limpiasen, empedrasen y reparasen en lo necesario ${ }^{14}$. Se despachó aviso a la

${ }^{8}$ Ibidem, ayuntamientos de 2 y 4 de febrero de-1701

${ }^{9}$ Ibidem, ayuntamiento de 5-2-1701. Los regidores elegidos fueron: marqués de Tejares, alférez mayor; Juan Antonio de Zárate; Manuel Fernández de Madrid; Diego Rafael Fernández de Madrid; Baltasar de Rojas; Rafael Hurtado; Francisco de Recalde; José de la Cuadra; Alonso José Fernández de Madrid; José de Segovia; José de Yepes y Sebastián de Pozo. Por parte de los jurados se escogió a Simón Zapata; Manuel Muñoz; Diego Romo; José Jacinto Sánchez; José de Illescas y Pedro de Salieres.

${ }^{10}$ A.M.T., libro de actas municipales de 1701, $\mathrm{n}^{\circ} 122$, ayuntamiento de 8 de abril

${ }^{11}$ MARTÍNEZ LEIVA, op. cit., (nota 3), p. 294

${ }^{12}$ A.M.T., libro de actas municipales de 1701, $\mathrm{n}^{\circ} 122$, ayuntamiento de 6 de mayo

${ }^{13}$ idem, ayuntamiento de 11 de julio. El Ayuntamiento no hace, con estas demostraciones, mas que cumplir protocolariamente con el personaje, sin entrar a prejuzgar su condición y situación actuales.

${ }^{14}$ Ibidem, ayuntamientos de 22 y 31 de agosto, los gastos ocasionados al Ayuntamiento por allanar el camino que iba desde la cerca del Hospital de Afuera a la iglesia de San Eugenio (cami- 
reina y se escribió a Portocarrero para que indicase qué protocolo había de ejecutar la ciudad en esta ocasión ${ }^{15}$. Por fin, Felipe $\mathrm{V}$ viajaba a Toledo dicho día 3 de agosto a visitar a la reina viuda. Fue recibido por el duque de Monteleón, como jefe de su Casa, en el alcázar y después mantuvo conversación privada con la soberana. Sin embargo, la ciudad no salió oficialmente a recibirle por ser visita privada y en secreto $^{16}$. Es decir, quedó al margen totalmente. La viuda de Carlos II lo agasajó con una espléndida comida en casa del Cardenal y le regaló un toisón de brillantes y una copa india de oro ${ }^{17}$, que el monarca agradeció vivamente. Nueva venida haría Felipe V a Toledo el 17 de septiembre de 1703, pero esta vez ni entraría en la ciudad ni iría a saludar a doña Mariana, sólo vino a pasar revista a los regimientos de caballería de sus guardias reales en la Vega ${ }^{18}$.

La estancia de la reina viuda en Toledo obligó al cabildo de la Iglesia Primada y al Ayuntamiento y sus capitulares a una serie de compromisos que trastocaron su regular vida. Nada más llegar anunció que deseaba oír dos misas diarias en la capilla de la Virgen del Sagrario - lo que trajo de cabeza a los canónigos, pues complicaba el orden establecido para los cultos de la catedral y la vida de los eclesiásticos, que tuvieron que ajustarla a los deseos de S.M., a la vez que supuso un gasto añadido al tener que pedir a los racioneros que dijesen las misas que los canónigos no podían celebrar y a los que se les remuneró con 12 reales por cada acto litúrgico-. Otros caprichos o deseos de la reina viuda, como imponerle la ceniza el Miércoles primero de Cuaresma en el Palacio Arzobispal o cambiar el lugar de lo sermones de Semana Santa, realizándolos desde el púlpito del evangelio del altar mayor de la catedral, pues así podía ver al predicador y atenderlos mejor desde la tribuna en la que ella se situaba sobre la capilla de San Pedro o el de rezar el rosario todos los sábados, con sus damas, desde el balcón de la capilla de la Virgen del Sagrario, dirigido por el sacristán mayor de la catedral o el que más tarde cambiara este último deseo por el de que la música de la Iglesia cantase una salve y letanía, lo que implicaba al maestro de capilla, al semanero, al maestro de ceremonias y a su ayudante, fueron atendidos por el cabildo catedralicio, aunque supusiese un inconveniente y un trastorno de la vida litúrgica del templo ${ }^{19}$

Los actos de cortesía le acarreaban al Ayuntamiento ciertos dispendios, como ya hemos podido comprobar. El día 29 de octubre de 1701 acudió el mayordomo más antiguo de la reina, don Vicente de Córdoba, caballero del hábito de Montesa, marqués de Castilnovo, para comunicar que la soberana tenía la intención de celebrar exequias por su difunto esposo en el Real Convento de Capuchinos de esta ciudad los días 3 y 4 de noviembre (el día 3 vigilia por la tarde y el 4 misa y sermón) y deseaba

no de Madrid), fueron de 564 rs. y 24 mrs., y los de reparar los otros caminos y calles ascendieron a 838 rs. y 25 mrs.

${ }^{15}$ Ibidem, ayuntamiento de 30 de julio

${ }^{16}$ Ibidem, ayuntamiento de 1 de agosto

${ }^{17}$ PRÍNCIPE DE BAVIERA, A., op. cit., (nota 2), pp. 315-318 y PRÍNCIPE DE BAVIERA, A. y MAURA GAMAZO, G.: op. cit. (nota 4), p. 1418

${ }^{18}$ A.M.T., libro de actas municipales de 1703, $\mathrm{n}^{\circ} 124$, ayuntamientos de 13, 17 y 19 de septiembre

${ }^{19}$ GARCÍA FERNÁNDEZ, África: Toledo Entre Austrias y Borbones: destierro de doña María Ana de Neoburgo, Toledo, 1995, Premio Nacional de temas toledanos: San Ildefonso 1994, pp. 102-104 
que acudiese el Ayuntamiento para mayor esplendor. La ciudad acordó asistir, pero como la mayoría de caballeros se hallaba de vendimia, se envió notificación a todos los que estuvieran en los contornos de Toledo para que acudiesen y lo hiciesen con capas de luto. Asimismo se determinó que los sofieles se vestirían con vestidos y capotes negros y llevarían las mazas cubiertas ${ }^{20}$.

El día 3 se reunieron los caballeros del cabildo del Ayuntamiento, todos de luto, como a las 15,15 horas y salieron con los sofieles con las mazas cubiertas de tafetán negro. En los coches que esperaban en la plaza del Ayuntamiento entraron: en el primero los cuatro sofieles; en el segundo los capellanes con bonetes y los dos contadores; en los siguientes los regidores y jurados, por orden de antigüedad. Cerrando el cortejo iba el Corregidor con tres caballeros regidores, los más antiguos de uno y otro banco, y el Secretario Mayor en el estribo. Detrás seguían cuatro ministros con vara y con vestidos y capas largas de luto, a pie. Después un coche de respeto, donde no iba persona alguna. Detrás otro coche en el iban el mayordomo y pajes del Corregidor. Al llegar se quedaron en dos filas ante el pórtico de la iglesia, como en procesión y actos públicos, con el Corregidor y los regidores más antiguos al final. Desde la puerta de la iglesia hasta la plazuela estaban los soldados de la guardia de la reina con sus alabardas en dos filas, haciendo calle. La ciudad pasó por medio y al llegar a la puerta de la iglesia se abrió la cancela y el padre guardián de los Capuchinos salió con la comunidad a recibir a las autoridades. Al mismo tiempo salió hasta las gradas del pórtico don Vicente de Córdoba, quien acompañó y acomodó en los bancos correspondientes a las dignidades de la ciudad. También acudió a las exequias don Diego de la Serna, caballero de la Orden de Calatrava, del Consejo de S.M. en el Real de Castilla. Ofició don Juan Pimentel y Zúñiga, canónigo de la catedral de Toledo, arcediano de Talavera y capellán de la Real Capilla de Reyes Nuevos. Al día siguiente, viernes 4 de noviembre, salió nuevamente la ciudad a las 10 horas, en la misma forma que el día antecedente, hacia el Real Convento de Capuchinos para asistir a la misa y sermón, donde fue recibida de la misma manera que el día anterior por el marqués de Castilnovo. Ofició el mismo eclesiástico y predicó fray Pedro Reinoso, lector de Teología en dicho convento ${ }^{21}$.

Mariana creyó que las relaciones con su sobrino iban a comenzar a caminar por unos derroteros más amistosos y cordiales, pero ella, excepto la invitación que ya hemos comentado hizo al monarca, no realizó mayores empeños para allanar el camino. Así, por ejemplo, cuando el Corregidor de Toledo le dio cuenta del casamiento de Felipe V con la princesa de Saboya y de que la ciudad iba a hacer demostraciones de júbilo para festejar el enlace, ella contestó que no acudiría a las ceremonias porque debía guardar luto y no podía hacer ostentación de alegría, aunque no se oponía a que las realizase la ciudad ${ }^{22}$; por el contrario, acabamos de ver cómo al tiempo que se celebraban los esponsales ella había programado una solemne función fúnebre en honor del difunto Carlos II $^{23}$; no obstante, el día del cumpleaños del rey (19 de

\footnotetext{
${ }^{20}$ A.M.T., libro de actas municipales de $1701, \mathrm{n}^{\circ} 122$, ayuntamiento de 29 de octubre

${ }^{21}$ Ibidem, ayuntamiento de 4 de noviembre

${ }^{22}$ Ibidem, ayuntamiento de 16 de noviembre

${ }^{23}$ SANZ AYÁN, Carmen, "La reina viuda Mariana de Neoburgo (1700-1706): primeras batallas
} 
diciembre), recibió a dos caballeros que el Ayuntamiento envió para besar su mano ${ }^{24}$ y para tener de su parte a la principal autoridad de la ciudad nombró al corregidor don Alonso Pacheco, conde de Ibangrande, su mayordomo, por decreto de 26-12-1701, de lo cual, tanto el mandatario como el resto de los caballeros del cabildo del municipio se congratularon y se designó a dos de sus componentes para que acudiesen a darle las gracias a la reina ${ }^{25}$, y además intercedió ante el monarca para que le prorrogase su mandato por otros tres años, quien así lo hizo por decreto de 11-9-170126

El inicio de la guerra de Sucesión truncó las esperanzas de Mariana (si es que las tenía), de reconciliación con el rey; por el contrario, se vio más aislada al expulsarse de España a todos los sospechosos de ser proaustriacos, entre ellos a varios personajes de su corte. La que más le dolió fue la de su confesor, única persona de confianza que le quedaba, fray Gabriel de Chiusssa, acusado de ser el instigador de que la reina viuda se negase a marchar a Francia y otros malos consejos ${ }^{27}$.

La guerra, que en principio se desarrolló en Europa, a partir de 1705 se trasladaría a España, convirtiéndose en una verdadera guerra civil. Aunque con muy diversos matices y el reconocimiento de la conjunción de factores complejos (que no son oportunos desarrollar en este artículo por no ser este nuestro objetivo), se puede generalizar diciendo que Castilla se inclinó a favor de Felipe V mientras Cataluña, Aragón, Valencia y Mallorca lo hicieron hacia el Archiduque Carlos -segundo hijo del emperador alemán-, en defensa del federalismo y de sus derechos forales y en contra del centralismo del que estaba haciendo gala el monarca de origen francés. Asimismo se produjo esta bipolarización según la actitud política de los nobles del reinado de Carlos II, unos defensores del poder para que nada se modificase y se perpetuase el anterior estado de cosas y otros resentidos por ver atacados sus privilegios y libertades y con la ambición de la oposición y la pretensión de una mudanza para conseguir poder y riqueza. En el clero tampoco hubo una actitud homogénea.

Si la desconfianza en la reina viuda no había desaparecido en los primeros momentos, controlándole incluso el correo con el fin de que no fuera fuente de información del bando austracista, aumentó con motivo de la entrada del Archiduque Carlos en España, así como de las tropas que le apoyaban (ingleses, portugueses y alemanes), pensando, y con razón, que ella le respaldaría; pensamiento que se agudizó cuando en 1706 se presentaron las tropas de Carlos III en Toledo -después de que este fuera investido rey en Madrid-, al mando del conde de La Atalaya (enviado por su tío el general marqués de Las Minas), para obligar a la ciudad -que había alzado

contra la invisibilidad", Las relaciones discretas entre las Monarquías Hispana y Portuguesa: las Casas de las Reinas (siglos XV-XIX) / coord.. por José Martínez Millán, María Paula Marçal Lourenço, vol. 1, 2009, pp. 474-475, señala la intención de Mariana de Neoburgo con esta ceremonia y el momento escogido de hacerse notar, hacerse visible y de autoafirmación, tesis de todo su artículo.

${ }^{24}$ Ibidem, ayuntamiento de 19 de diciembre

${ }^{25}$ Ibidem, ayuntamiento de 29 de diciembre

${ }^{26}$ Ibidem, notificación del Corregidor al Ayuntamiento el 12 de septiembre y cédula de nombramiento de S.M. de 1 de octubre, presentada a la corporación en el ayuntamiento de 27-1-1702

${ }^{27}$ PRÍNCIPE DE BAVIERA y MAURA GAMAZO, op. cit., (nota 4), p. 1421; el día 18 de enero de 1702 ya estaba en Parma y el 1 de abril se hallaba en Roma, p. 1422 
bandera por Felipe-, a entregarse al candidato Austria y ser acogidas con entusiasmo por doña Mariana y Portocarrero, quien se había pasado al bando del Archiduque.

Toledo siempre se había mostrado fervorosa partidaria de Felipe V tal y como lo demostró en todas las ocasiones que se le ofrecieron. Sólo hubo algunas excepciones, aunque significativas, y actuaciones poco claras en ocasiones. Fue de las primeras ciudades que levantaron bandera por el nuevo rey ${ }^{28}$; festejó su llegada, su entronamiento, su boda con María Luisa Gabriela de Saboya y todos sus triunfos; no dudó en hacer grandes sacrificios económicos -tanto como para endeudarse por mucho tiempo-y personales para atender las necesidades del monarca en los momentos de mayor apuro y levantó compañías para engrosar su ejército; pero la situación en 1706 fue muy crítica. En junio se instituyó una junta de guerra, se crearon compañías por los gremios, se preparó la ciudad para la defensa y su Ayuntamiento -que mantenía su fidelidad a Felipe V-, buscó apoyo en el cardenal Portocarrero, el cabildo catedralicio y el tribunal de la Inquisición. Las dos instituciones se pusieron a disposición de la ciudad, pero el prelado, que había suspendido su venida a Toledo, prevista para el día 20, contestó a los caballeros comisionados "Cuánto estimaba la atención de la ciudad y que dar dictamen positivo sobre ello, no podía hacerlo, sí sólo concurrir a lo que fuere de la mayor satisfacción de la ciudad y que siempre sería fiel testigo con S.M. de la lealtad, amor y celo de este Ayuntamiento"29. Es decir, ahora, como en otros momentos que veremos posteriormente, se muestra cauto y precavido, sin involucrarse demasiado con nadie, en espera de ver hacia dónde se inclinaba la balanza definitivamente.

El día 26 llegó una carta al Ayuntamiento de don Baltasar de Rojas en la que anunciaba que Madrid se había rendido a las tropas del pretendiente Carlos III de Austria. Se fue en busca del Corregidor para darle la noticia y no se le encontró, había huido. El día 27 se leyó una carta del conde de Ibangrande por la que excusaba su ausencia y decía que mientras él faltase nombraba como Teniente de Corregidor al caballero regidor más antiguo. El marqués de Tejares, José Antonio Niño de Guzmán y Silva -que en octubre de 1704 había sido nombrado por doña Mariana su mayordomo y en estos momentos estaba ejerciendo como tal en el alcázar-, en el ayuntamiento del día 28 expuso que ante la seguridad de que el Corregidor no había de volver, el cabildo de caballeros debía nombrar uno y se dejase al Alcalde Mayor en su empleo. La ciudad acordó presentar el asunto a la reina viuda y al cardenal Portocarrero. Aquella -que no atendió a los caballeros comisionados con la excusa de hallarse enferma y no quiso expresar públicamente su opinión-, contestó a través del conde Alba de Aliste que la ciudad podía hacer lo que creyera más conveniente y que ello sería de su agrado; el prelado -escurridizo como de costumbre- respondió que no podía emitir dictamen y que la ciudad se atuviese a lo que dijeran los abogados. En la sesión de ayuntamiento extraordinario del día 29, tras largo debate, se acordó

${ }^{28}$ Fue el regidor don Pedro de Robles y Toledo el encargado de acudir a Madrid para dar cuenta del hecho. Se le quiso abonar 50 pesos por "correr la posta", pero él se negó a aceptarlos diciendo que lo había realizado por lealtad y servicio. De todas formas el Ayuntamiento aprobó que se le pagasen, A.M.T., $2^{\circ}$ libro de actas capitulares de 1700, $\mathrm{n}^{\circ}$ 121, ayuntamiento de 21-1-1701

${ }^{29}$ A.M.T., libro de actas capitulares de 1706, $\mathrm{n}^{\mathrm{o}} 127$, ayuntamiento de 23 de junio 
nombrar por Corregidor al marqués de Tejares -quien confirmó como Teniente de Corregidor y Alcalde Mayor a don Francisco Gutiérrez de Castilla- y que se pasase a notificar dichos nombramientos a doña Mariana y al Cardenal. La reina viuda expresó su contento y agrado, el prelado su gran gusto y estimación por el nombramiento y el marqués de las Minas le confirmó como tal -aunque el marqués intentó excusarse de manera un tanto hipócrita, diciendo que se buscase otra persona más desocupada, pues él se hallaba precisado a servir el empleo de mayordomo de la reina viuda-, exigiéndole que mantuviese en quietud la ciudad y llevara a cabo el cobro de las rentas reales.

El día 30 de junio se recibió carta del marqués de las Minas -escrita en portuguésexigiendo la obediencia de la ciudad de Toledo a Carlos III. El Ayuntamiento se muestra desconcertado y decide enviar embajadas a la reina viuda, al cardenal, al cabildo catedralicio y al tribunal de la Inquisición para recabar sus impresiones. Doña Mariana respondió por medio del cardenal -que se hallaba con ella cuando llegó la embajada del Ayuntamiento- que lo que ejecutase la ciudad sería del mayor acierto, pero, con ladina intención, expuso que no se excusaba manifestar en el lance presente que se debía mirar las fuerzas del enemigo y las pocas prevenciones con que Toledo y las villas de su jurisdicción se hallaban, con lo que parece dar a entender de manera diplomática que la ciudad no debía oponerse a las tropas austracistas y permitir su entrada sin oposición. Portocarrero, más prudente, dijo que resolviese la ciudad lo más prontamente posible. El Tribunal, que le parecía dar obediencia a la petición del marqués de las Minas, pero que quedaba a satisfacción de la ciudad. El Cabildo, que estaría con la ciudad en lo que acordase. Vistas las contestaciones dadas por las personalidades e instituciones, que oscilaban según la coyuntura, obligado por las circunstancias y a petición del marqués de Tejares, el Ayuntamiento toledano decidió, por unanimidad, prestar obediencia a Carlos III -esperando de su real gratitud que mantendría los privilegios y honras de la ciudad-. El 1 de julio se recibió carta del marqués de las Minas en la que expresaba su agradecimiento por lo convenido por la ciudad y que lo restante que hubiera de decidir lo hiciera previa consulta con doña Mariana de Neoburgo ${ }^{30}$.

El conde de la Atalaya se presentó en Toledo con 50 guardias de a caballo para cumplimentar a la reina viuda y presionar a la ciudad a fin de que no cambiase su postura. El Ayuntamiento, en prevención de conflictos, acordó poner rondas extras por los barrios para evitar los corrillos y reducir los vecinos a sus $\operatorname{casas}^{31}$. En la sesión del Ayuntamiento de 6 de julio, se tomó el acuerdo, entre otros, tras pedir opinión a doña Mariana y al cardenal Portocarrero, de fijar para el día 10, sábado, el levantamiento del estandarte real para proclamar como rey a Carlos III de Austria. Ambos personajes se dieron por contentos y bien servidos con esta decisión. El cabildo catedralicio expuso que veía bien lo determinado por el Ayuntamiento y que cooperaría con lo que se acostumbraba en estos casos.

${ }^{30} \mathrm{Ib}$ idem, ayuntamientos del 26 de junio al 1 de julio. Prueba inequívoca de su posicionamiento político, pues si no, ¿por qué habría de implicarla en las resoluciones que debía tomar la ciudad?

${ }^{31}$ Ibidem, ayuntamientos de 4 y 5 de julio 
Según lo acordado, el día 10 se alzó el pendón por Carlos III de Austria en el Ayuntamiento y después se pasó a la catedral para su bendición y jurarle como rey de España -acto al que asistieron los dos personajes antedichos-. Después subió la ciudad al alcázar a caballo. La reina salió al balcón que llamaban "del atambor", donde se había puesto sitial y dosel, y el estandarte fue colocado en la torre por el alcaide del alcázar, Diego Fernández de Velasco. Doña Mariana, desde el balcón, arrojó al pueblo gran cantidad de monedas de oro, plata y vellón ${ }^{32}$.

La actuación de Portocarrero y de doña Mariana causó admiración a propios y extraños. El Cardenal iluminó su casa, preparó una espléndida función en la catedral en la que cantó el Tedeum, bendijo las banderas del austriaco y obsequió a los oficiales del Pretendiente con una espléndida comida en el Palacio Arzobispal, en la que se brindó por Carlos III. La reina, mujer impulsiva y ambiciosa, en señal de alegría dejó sus atuendos de viuda y vistió sus mejores galas el día de la proclamación, a la vez que se las hacía vestir a su servidumbre; adornó de fiesta el palacio y escribió a su sobrino el rey Carlos era hijo de su hermana la emperatriz Eleonora-, una carta de adhesión y le obsequió con joyas de alto valor. Estaba exultante pues el conde de la Atalaya le había ofrecido que quedaría como gobernadora del reino hasta tanto que Carlos III lograra alzarse vencedor de la contienda y comenzara su reinado en toda España ${ }^{33}$

Sin embargo, los gremios de Toledo, descontentos con esa imposición ${ }^{34}$, el día 18 se rebelaron y se alzaron en armas tras la marcha del pequeño ejército aliado, enarbolando estandarte por Felipe V. Eligieron por capitán a don Diego de Toledo Guzmán y Calatayud, quien aceptó con la condición de que no se tomaran represalias ni se hicieran actos vandálicos contra la reina viuda, el cardenal y los caballeros del Ayuntamiento. Estos, desorientados, cogidos entre dos fuegos y con el marqués de Tejares huido a Madrid, trataron de hallar alguna luz buscando la ayuda de los personajes e instituciones ya antedichas. Nadie deseaba pronunciarse abiertamente y sólo obtuvieron evasivas o vaguedades. Por fin, el día 21 se tomó el acuerdo unilateral de ratificar la obediencia y juramento de fidelidad que la ciudad tenía dados a Felipe V, manteniéndose en su lealtad. Se ordenó comunicar esta decisión a doña Mariana,

${ }^{32}$ A.M.T., libro de actas capitulares de 1706, n⿳0 127.

${ }^{33}$ BACALLAR Y SANNA, V. (marqués de San Felipe): Comentarios de la guerra de España e Historia de su rey Felipe el Animoso, Génova, 2 tomos, pp. 217 y 218. No obstante este autor cree que doña Mariana actuó así por las persuasiones del cardenal Portocarrero y arrastrada por el afecto al hijo de su hermana, la emperatriz viuda. Nosotros pensamos tras lo expuesto, que la reina estuvo lo suficientemente implicada en la intención de entronización de su sobrino y se manifestó de manera más comprometida por propia iniciativa, pero no por incitaciones del cardenal, a no ser que este, más ladino, supiese inducirla a manifestarse por ser más impulsiva y quedar él en la sombra.

${ }^{34}$ JIMÉNEZ DE GREGORIO, F.: Los pueblos de la provincia de Toledo hasta finalizar el siglo XVIII, Toledo, t. V., Toledo, 1986, en la p. 545 nos dice: "Toledo recibió a la regia desterrada con alegría". Y en la 547 expresa la opinión de que " Tanto ésta como Portocarrero y el pueblo, se unen y aclaman al austriaco..." y "Toledo proclamó como rey de España al archiduque, al parecer, con entusiasmo, porque entre el pueblo contaba la reina viuda con simpatías", afirmaciones gratuitas como lo demuestra que el Ayuntamiento hubiera de disponer rondas extraordinarias para evitar disturbios con los guardias del conde de la Atalaya y la posterior sublevación de los gremios a favor de Felipe V, obligando al Ayuntamiento a rectificar y volver a la obediencia y fidelidad del Borbón tras haberse rendido a Carlos III. 
al cardenal, al tribunal de la Inquisición y al cabildo catedralicio y publicarla en las calles y plazas acostumbradas. El tribunal de la Inquisición celebró con entusiasmo la decisión, señalándola de acertada, añadiendo que alistaría a todos sus ministros, enarbolaría banderas y se pondría a la orden de la ciudad. El cabildo de la catedral comunicó al Ayuntamiento que entendía que su postura era la más conforme a la grandeza de Toledo y a la quietud pública, que realizaría peticiones a la divinidad por el éxito de la empresa y que haría novenas a la Virgen del Sagrario por la paz de esta república y tranquilidad del reino ${ }^{35}$.

Un hecho un tanto singular ocurrió por estas fechas. El Ayuntamiento había mandado, para enarbolar el estandarte por Felipe V que había de traer Diego de Toledo desde el Arco de la Sangre, en Zocodover, donde había sido colocado por los gremios, adornar las casas consistoriales por dentro y por fuera y colocar en el balcón de hierro de la galería, debajo de un dosel, los retratos del rey y de su esposa. Al pasar dicho caballero a caballo por la plaza del Ayuntamiento y ver aquella demostración, mandó quitar los retratos y la almohada. El Ayuntamiento, asombrado por tal decisión, envió una embajada al cardenal Portocarrero. Este entendió el problema -que sólo era debido a un prurito de protagonismo y preponderancia-, e intercedió ante Diego de Toledo, el cual se avino a traer el pendón real esa tarde al Ayuntamiento para entregarlo a quien acordase la ciudad y ordenó volver a poner el dosel, los retratos de los reyes y la almohada como estaban antes y que se echase bando para que los vecinos pusiesen esa noche luces y luminarias en sus casas. Al día siguiente la corporación municipal acordó ofrecer a Diego de Toledo que fuese él quien blandiese el pendón real desde el balcón del Ayuntamiento, a la vez que se enviaba una embajada al Cardenal para darle las gracias por su mediación y que hiciera posible que la ceremonia de izar el real estandarte por Felipe V se realizase desde las casas de dicha institución. A las 17,30 horas fue enarbolado el estandarte real con toda pompa y solemnidad por don José Antonio de la Cuadra y Olando, regidor más antiguo - por excusarse don Diego de hacerlo-, el cual había sido traído por este personaje acompañado por algunas compañías de soldados formadas por los gremios, aunque demandó que después del acto debía tomarlo él y lo conduciría, acompañado por los caballeros capitulares, a la catedral, donde lo entregaría al preste para que fuese colocado en el templo. Así fue aceptado por la ciudad. La ceremonia fue observada por numeroso público que aclamaba incesantemente a los reyes a la vez que movía lienzos blancos en manifestación de regocijo ${ }^{36}$.

Tras el retorno a la obediencia de Felipe $\mathrm{V}$ por parte de la ciudad, el marqués de las Minas la conminó por carta del día 27 a que rectificase y la amenazó con obligarla por la fuerza, a la vez que escribió al cardenal Portocarrero para que mediase en su rendición; pero el Ayuntamiento rechazó las exigencias del jefe del ejército aliado y se dispuso a la defensa de Toledo haciendo acopio de trigo, armas y municiones. Se pidió un préstamo de 20.000 ducados al cabildo de la catedral para hacer frente a todos los gastos que se precisasen y como éste respondió que sólo lo concedería

\footnotetext{
${ }^{35}$ A.M.T., libro de actas capitulares de 1706, $\mathrm{n}^{\circ}$ 127, ayuntamientos de 20, 21 y 22 de julio

${ }^{36}$ Ibidem, ayuntamientos de 25 (dos de ellos extraordinarios) y 28 de julio
} 
si toda la ciudad se comprometía a devolverlos en caso de no conseguir la facultad de un nuevo impuesto, los caballeros capitulares acordaron hacerse cargo de la devolución del préstamo a prorrateo, con sus bienes. Entonces el cabildo catedralicio se vio obligado a ofrecer al Ayuntamiento 1.000 doblones graciosamente, sin que tuviese la ciudad que devolverlos; pero en caso de que siguiese con la idea de tomar los 20.000 ducados en préstamo, estos 1.000 doblones entrarían a formar parte de dicho capital., condición aceptada por el Ayuntamiento ${ }^{37}$.

Como vimos, el marqués de Tejares, junto al cardenal Portocarrero y doña Mariana, había actuado de manera inequívoca e influyente a favor de la aceptación por Toledo del pretendiente Carlos de Austria como rey de España. Inmediatamente, una vez la ciudad había vuelto a la obediencia de Felipe V, se recibió carta del Presidente de Castilla -que se hallaba en Atienza con el rey y su ejército- nombrando como Corregidor a don Diego de Toledo, ratificada por otra de 3 de agosto señalando que además conllevaba el nombramiento de Superintendente General de Rentas Reales ${ }^{38}$.

De todo lo sucedido en Toledo se informó a Felipe V, así como de la inclinación tan manifiesta de la reina hacia su contrincante. El Ayuntamiento recibió el día 21 de agosto la noticia de que la reina viuda tenía orden de salir de la ciudad para Burgos y despachó una embajada para despedirla. El monarca envió al duque de Osuna y conde de Pinto con doscientos dragones ${ }^{39}$ y sacaron a doña Mariana de la ciudad el 22 de agosto -bajo los insultos de "cervecera" por parte de numerosos toledanos-, conduciéndola a Bayona. Ella había querido que la dejaran en El Escorial, pero tanta insistencia trajo las sospechas del duque y del monarca, además de que lo que se pretendía era alejarla lo más posible de la corte y trasladarla a un lugar donde pudiese estar controlada.

La ciudad, mientras tanto, continuó preparándose para su defensa. Como faltaba efectivo pidió a los caballeros capitulares, vecinos, cardenal, capilla de Reyes Nuevos, Reyes Viejos y a todas las comunidades religiosas, que cada cual entregase lo que pudiese. El Cardenal contestó que daría cuenta más tarde de los acuerdos tomados; los capellanes de la capilla de Reyes Nuevos, que sólo podían contribuir con 202 fanegas, 10 celemines y 2/5 de trigo; los capitulares del Ayuntamiento cedieron sus salarios por tres años; el cabildo catedralicio entregó 6.000 fanegas de trigo y el cabildo de jurados ofreció 8.000 rs. ${ }^{40}$.

Como última incidencia con respecto a doña Mariana de Neoburgo, el Corregidor recibió noticias de que en el alcázar se sospechaba habían quedado "algunas prevenciones ocultas"y mandó hacer un registro por "maestros y gente que les asistan", a quienes acompañarían algunos caballeros comisionados ${ }^{41}$.

\footnotetext{
${ }^{37} \mathrm{Ib}$ idem, ayuntamientos $2^{\circ}$ extraordinario de los días 28 y 31 de julio y 3 y 4 de agosto

${ }^{38} \mathrm{Ibidem}$, ayuntamientos de 29 de julio y 8 de agosto

${ }^{39}$ MARTÍN GAMERO, A.: Historia de la ciudad de Toledo, Toledo, 1862, segunda parte, edición de 1979 , p. $984,\left(2^{\circ}\right.$ vol. $)$

${ }^{40}$ A.M.T., libro de actas capitulares de 1706, $\mathrm{n}^{\mathrm{o}} 127$, ayuntamientos de 6, 19, 23 y 30 de agosto y 4 y 6 de septiembre

${ }^{41}$ A.M.T., libro de actas capitulares de 1706, $\mathrm{n}^{\circ}$ 127, ayuntamiento de 27 de agosto. No debió hallarse nada importante pues no se registra noticia alguna.
} 


\section{Incidencia económica}

Como consecuencia de la guerra, el Ayuntamiento se llenó de deudas a causa de las contribuciones que voluntaria o preceptivamente otorgó a Felipe $V$ para la continuación de la guerra y necesidades de la monarquía y las que los aliados obligaron de manera forzosa pagar al consistorio. A falta de recursos para cancelarlas hubo de declararse en quiebra y sus acreedores se incautaron de todas las rentas ${ }^{42}$. El costo que la estancia de las tropas del archiduque le supuso a Toledo ascendió a 436.202 rs. y 26 mrs. Después de la serie de contribuciones de guerra, Toledo debía $11.064 .394 \mathrm{mrs}^{43}$. Por el contrario, la permanencia de Mariana de Neoburgo en Toledo produjo un aumento del comercio en la ciudad y unas ganancias adicionales a los agricultores, comerciantes, mercaderes y artesanos, debido a las mercancías con que había que abastecer las necesidades de su Casa., así como unos ingresos añadidos al municipio con el abono de derechos de puertas de los diversos géneros que consumía.

A la reina viuda se le dejó, por voluntad de su difunto marido Carlos II, una asignación anual de 400.000 ducados de por vida, según las cláusulas 34 y 35 de su testamento; pero por los gastos que acarreaba la guerra no se le abonaban en su totalidad, además de que parte de su pensión se le retraía para sustentar a las doscientas mujeres que estuvieron a su servicio pero que se negaron a acompañarla en su destierro en Toledo. Por otra parte se le negaba el dinero porque se le acusaba de haber permitido la salida de millones hacia Alemania, en especial la condesa de Berlepsch ${ }^{44}$ y porque se la consideraba sospechosa de apoyar al Archiduque y a sus partidarios en España.

Siguiendo las cartas de pago recibidas por la Casa real de Mariana de Neoburgo, los contratos de provisión y otros documentos que se conservan en los protocolos del Archivo Histórico Provincial de Toledo (A.H.P.T.), correspondientes a los cinco años y medio (9-2-1701 a 22-8-1706) que la soberana permaneció recluida en la ciudad, podemos hacernos una idea del beneficio que señalamos para el comercio de la capital y su entorno.

Una de las partidas más importantes era la del alumbrado: cera y velas de sebo. En cuanto a la cera, el primer contrato se realiza el 23 de febrero de 1701. Por él, Pedro del Val y Heredia, cerero, fiado por Lorenzo del Val y Heredia, su hermano, ambos vecinos de Toledo, se obligó a entregar a la Casa de la reina toda la cera que necesitase, por un año, empezando el 1 de marzo. Tanto la contrahecha como la ordinaria blanca se le pagaría a 8 rs. la libra y la amarilla a 7 rs. ${ }^{45}$. La cuenta ascendió a $2.917 .973 \mathrm{mrs}$., que se le abonaron por el tesorero de la reina viuda, don Juan Tomás de Goyeneche

\footnotetext{
${ }^{42}$ RAMÍREZ DE ARELLANO, R.:“Toledo en la guerra de Sucesión de 1700 a 1710”, BRABACHT, no 3 y 4 (abril págs. 97-117 y julio págs. 129-142), Toledo, 1929, pp. 104-105

${ }_{43}$ A.M.T., Carpeta Guerra de Sucesión, Vecindario por parroquias (1703-1717) y Carpeta Guerra de Sucesión, Vecindario por parroquias, 193

${ }^{44}$ PRÍNCIPE DE BAVIERA y MAURA GAMAZO, op. cit., (nota 16), pp. 1413 y 1414 respectivamente

${ }^{45}$ Archivo Histórico Provincial de Toledo (A.H.P.T.), prot. 562, escribano Antonio de Villoslada, fol. 36
} 
el 14-3-1702 ${ }^{46}$. El mismo cerero se obligó el 1 de abril de 1702 a proveer de toda la cera necesaria desde el 1 de marzo de ese año, ya que la anterior obligación había finalizado el 28 de febrero, a los mismos precios y calidades. En esta ocasión no habría limitación de tiempo. Se obligaba a entregar la cera con toda puntualidad e iría cobrando mensualmente. Se le guardarían todas las prerrogativas, honras y preeminencias de que gozaban los proveedores de la real $\mathrm{Casa}^{47}$. El 12 de octubre Pedro del Val extendió carta de pago por valor de 35.000 rs.(1.190.000 mrs.), que había recibido a través de la nómina del gasto general de dispensa causada por todos los oficios y proveedores de la Casa de la reina viuda ${ }^{48}$. El 3 de enero de 1703 otorgó carta de pago de haber recibido de Diego Jiménez Cascante, tesorero interino, grefier y caballerizo de S.M. la reina viuda, 41.244 rs.(1.402.296 mrs.) por el resto de la cera entregada el año $1702^{49}$. Durante el año 1703 fueron consumidas por la Casa de doña Mariana 10.948 libras de cera contrahecha y blanca y 741 libras y 3 onzas de amarilla. El dinero que recibió por ello Pedro del Val fue de 3.154.256 mrs. -ya que los precios de las distintas clases de cera se mantenían inmutables-, por lo que otorgó carta de pago el 16 de junio de $1704^{50}$. Sin embargo, el 5 de julio de este último año, firmó una obligación para la provisión de cera por un año, pero ahora el precio variaba, se efectuaba una subida de un real por libra de cera; es decir, la blanca a 9 rs. y la amarilla a 8 rs. aunque con el pago de derechos reales por su cuenta ${ }^{51}$ y el 21 de julio del año siguiente volvió a obligarse a la provisión de cera a la Casa de la reina al mismo precio; pero puso dos condiciones nuevas: que a cuenta de lo que se le debía del año anterior, en principio se le había de abonar el importe de los meses de abril y mayo y luego se le pagaría mensualmente y que él sólo abonaría la mitad de los derechos reales de alcabalas y cientos conforme el estilo que generalmente pagaba el comercio de Toledo $^{52}$.

En lo que respecta a las velas de sebo, el 23 de septiembre de 1701, Francisco Miguel, vecino de Toledo, se obligó a favor de la reina viuda a la provisión de todas las que necesitase su real Casa, por tiempo de un año, que empezaría a rezar desde el 1 de octubre. El precio se estipuló en 10 cuartos ( $40 \mathrm{mrs}$.) la libra durante los primeros seis meses y en 11 cuartos (44 mrs.) los restantes. Había de proveer un mes anticipado las velas que se necesitasen, por razón de fianza y al final de cada mes se ajustaría la cuenta. El sebo que precisase para su fabricación habría de entrar libre en la ciudad, sin que tuviese que pagar ningún derecho y se le debían guardar todas las excepciones, honras y preeminencias que al resto de proveedores de la Casa real ${ }^{53}$. El 22 de noviembre de 1702 es Manuel Mozo, igualmente vecino de Toledo, quien se obligó a la provisión de velas de sebo por un año que daba comienzo desde el primer día del mes. Las condiciones que se establecieron son las siguientes ${ }^{54}$ :

\footnotetext{
${ }^{46}$ Ibidem, fol. 486

${ }^{47}$ Ibidem, fol. 506

${ }^{48}$ Ibidem, fol. 780

${ }^{49}$ A.H.P.T., prot. 3936, escribano Antonio de Villoslada, fol. 3

${ }^{50}$ Ibidem, fol. 726

${ }^{51} \mathrm{v}$, fol. 756

${ }^{52}$ A.H.P.T., prot. 563, escribano Antonio de Villoslada, fol. 185

${ }^{53}$ A.H.P.T., prot. 562, fol. 237

${ }^{54}$ Ibidem, fol. 815
} 
-Las velas habían de ser de buena calidad, sin más mezcla que sebo de macho y carnero.

-Cada libra se le pagaría a 13 cuartos (52 mrs.)

-El otorgante abonaría todos los derechos que hubiere.

-Recibiría 2.000 rs. por adelantado.

-Se le ajustaría la cuenta a fin de cada mes, deduciendo en los dos primeros meses el dinero adelantado.

-Se le habían de pagar 1.063 rs. que se le estaban debiendo de las velas de sebo que había provisto anteriormente.

-Se le habían de guardar las exenciones y preeminencias de que gozaban los proveedores de la real Casa.

El 6-9-1703 Águeda Rodríguez, viuda de Silvestre Rodríguez, fiada por Mateo de la Peña, ambos vecinos de Ajofrín (Toledo), otorgaron que se obligaban a favor de la reina viuda a proveer a su real Casa de todas las velas de sebo que fuesen necesarias y que les pidiesen para su consumo, dando principio este encargo en el día de la fecha, el cual permanecería vigente mientras no se diese aviso de cese. Todas las velas habían de ser de la fábrica de Ajofrín, de buena calidad y sin más mezcla que sebo de macho y carnero, al precio de 40 rs/arroba. Los otorgantes se hacían cargo de todos los derechos reales que hubiese que pagar ${ }^{55}$. La misma, fiada ahora por su hijo Juan Rodríguez, se obligó el 21-5-1704 a la provisión de velas de sebo al precio a 12 cuartos (48 mrs.) la libra, por un año a partir del 1 de abril. La calidad y las demás condiciones se repiten con la salvedad de que la cuenta se satisfaría a fin de cada mes y debía ser considerada como proveedora de la Casa real ${ }^{56}$.

Un artículo totalmente necesario era el del pan, por eso, junto a la cera-producto ya visto- al carbón y la cebada y paja para las caballerizas, fueron los que con mayor prontitud se contrataron y que mayor número de partidas incluyen.

El 19-2-1701 el panadero Roque de Burgos, fiado por el arriero Ventura Martín, ambos vecinos de Toledo, se obligó a favor de la reina a entregar en la "panetería" de su real Casa la cantidad de pan que cada día se le pidiere ${ }^{57}$.

\footnotetext{
${ }^{55}$ A.H.P.T., prot. 3936, fol. 290

${ }^{56}$ Ibidem, fol. 712

${ }^{57}$ A.H.P.T., prot. 562 , fol. 30
} 
-Los panes serían de 2 libras cada uno y a satisfacción del sumiller de la panetería.

-Cada pan se le pagaría a $22 \mathrm{mrs}$.

-Comenzaría con la obligación el 1-3-1701 hasta el 31-7-1701.

-Recibió anticipadamente para comprar trigo u otras prevenciones, 3.000 rs., que se le irían descontando en el curso de su obligación.

-Todo el pan que le sobrase después de haber entregado lo necesario a la Casa real, lo podría vender a quien quisiese y por el precio que pudiese.

-Se le reconocía el goce de prerrogativas y preeminencias de los proveedores de la Casa real.

El mismo panadero, fiado en esta ocasión por Valentín Fernández y Francisco del Cerro, todos panaderos y vecinos de Toledo, se obligó el 6 de septiembre a la provisión de pan común a la real Casa de la reina viuda, por término de un año, pero al precio de $20 \mathrm{mrs}$. cada pan de dos libras menos onza, según estilo. La citada obligación se entiende iniciada desde el día 1 de agosto y para comprar trigo y otras prevenciones recibió 10.000 rs., que se le irían descontado en el transcurso del compromiso $^{58}$. El 23 de marzo de 1702 otorgó carta de pago de haber recibido de Juan Tomás de Goyeneche 7.403 rs. (591.702 mrs.): $251.702 \mathrm{mrs}$. del importe del pan que proveyó desde 2-2-1701 hasta 31-7-1701; y los 340.000 mrs.(10.000 rs.) restantes para comprar trigo al tiempo de la cosecha por ser el que se compraba más barato, para la provisión del pan de 1-8-1701 hasta 31-7-170259. A partir del 1 de agosto se quedó con el suministro Martín de Saunaque, residente en Toledo y panadero de boca de la reina viuda, al mismo precio y condiciones de cada pan que el anterior proveedor, aunque éste recibiría 12.000 rs. anticipadamente. Agotado el dinero adelantado, se le había de proporcionar lo que necesitase para poder seguir con su compromiso y al final se ajustaría la cuenta total, abonándosele en lo que estuviera alcanzado ${ }^{60}$. Terminado el compromiso de su licitación volvió Roque de Burgos, panadero en el horno de la tahona de Toledo, fiado por Francisco del Cerro, panadero en el horno de la Magdalena y Valentín Fernández, en el de la Oliva, a quedarse con la obligación rebajando el precio de cada pan a 18 mrs., asimismo por tiempo de un año. Para la compra de trigo se le entregaría al principal 6.000 rs. entre el día 1 y el 20 de agosto y otros 1.000 rs. a mediados de septiembre, los cuales 7.000 rs. se le irían descontando del pan que entregase cada día y, extinguidos, se ajustaría la cuenta y se le iría pagando de mes en mes lo que se le debiera y al final de la obligación se

\footnotetext{
${ }^{58}$ Ibidem, fol. 217

${ }^{59}$ Ibidem, fol. 497

${ }^{60}$ Ibidem, fol. 693
} 
cancelaría la cuenta con el pago tota ${ }^{61}$. Martín de Saunaque volvió a echar un nuevo pliego para quedarse con la provisión de pan a la Casa de la reina viuda por un año desde el 1-8-1704, ganando la licitación al ofrecer un precio de $18 \mathrm{mrs}$. cada pan durante los primeros ocho meses y de $16 \mathrm{mrs}$. los cuatro restantes. El otorgante había de recibir como anticipo 4.000 rs. y luego 3.000 rs. el 30 de septiembre de ese año. Los 7.000 rs. se descontarán al final de la cuenta ${ }^{62}$ De nuevo fue Roque de Burgos, con los mismos fiadores, quien obtuvo el encargo de aprovisionar de pan a la Casa de doña Mariana desde el 1-8-1705, al precio de $19 \mathrm{mrs}$. los seis primeros meses y de 18 mrs. los restantes. Recibió anticipadamente 7.000 rs. que se irían saldando desde el primer día de la provisión hasta marzo de 1706. A partir de este mes recibiría otros 3.000 rs., que se irían enjugando en los meses siguientes. Las cuentas se ajustarían al final de cada mes y recibiría el dinero que restase entre el valor de la mercancía entregada y la parte a extinguir del anticipo. El pan lo había de poner diariamente en la real panetería a su costa ${ }^{63}$.

Juan de Mora, vecino de San Pablo de los Montes, se obligó el 2-6-1701 a entregar 6.000 arrobas de carbón al precio de $64 \mathrm{mrs}$./arroba, libres de otros gastos. La entrega sería hasta el 30 de septiembre. Los gastos por derechos de puertas, puentes y otros, serían por cuenta de la Casa real ${ }^{64}$. Por escritura de 10-5-1702, Francisco de Perea, mesonero, fiado por Simón Guerrero, ambos vecinos de Toledo, se obligó a servir a la Casa de la reina viuda 12.000 arrobas de carbón de encina de buena calidad al precio de 20 cuartos $(80 \mathrm{mrs}$.). Los gastos de entrada y demás que hubiere serían por cuenta del otorgante. El contrato daría comienzo el 20 de mayo y finalizaría el 31 de octubre de 1702. Se le habían de entregar 9.000 rs. de anticipo para los gastos de quema de leña y conducción del carbón. Una vez que constase haber entregado 8.000 arrobas, se le habían de dar otros 9.000 rs., y finalizada la entrega se liquidaría la cuenta total ${ }^{65}$. Francisco recibe 9.000 rs. de Juan Tomás de Goyeneche el 12-101702, 10.000 rs. de Diego Jiménez de Cascantes el 3-1-1703 y 5.176 rs. y 16 mrs el 24 de abril de este mismo año ${ }^{66}$. Por su parte, Julián de Encinas, presbítero de Toledo, confesó haber recibido el 9-7-1703 del tesorero 2.410 rs. y 32 mrs. por 1.242 arrobas de carbón al precio de 66 mrs./arroba ${ }^{67}$; el 10-10-1704 Francisco Núñez Sotomayor, vecino de Urda, admitió haber recibido del dicho tesorero 10.484 rs. y 16 mrs. por el importe de 4.951 arrobas de carbón entregado a precio de 18/4 la arroba (72 mrs.), libre de portazgo ${ }^{68}$; el 20-10-1704 Mateo Díaz de Hita, vecino de Toledo, declaró haber recibido del mismo tesorero 4.000 rs. por el precio de 2.000 arrobas de carbón que entregó durante el año $1703^{69}$; el 30-9-1705, Francisco Núñez Sotomayor, vecino de Urda y residente en Toledo, reconoció haber recibido del mismo personaje 648.000

\footnotetext{
${ }^{61}$ A.H.P.T., prot. 3936, fol. 242

${ }^{62}$ Ibidem, fol. 764

${ }^{63}$ A.H.P.T., prot. 563 , fol. 543

${ }^{64}$ A.H.P.T., prot. 562, fol. 92

${ }^{65}$ Ibidem, fol. 560

${ }^{66}$ A.H.P.T., prot. 562 , fol. 781 y prot. 3936 fols. 4 y 132, respectivamente

${ }^{67}$ A.H.P.T., prot. 3936 , fol. 209

${ }^{68}$ Ibidem, fol. 860

${ }^{69}$ Ibidem, fol. 864
} 
mrs. por el importe de 9.000 arrobas de carbón que se había obligado a entregar para el gasto de dicho año a precio de 18/4 $\operatorname{arroba}^{70}$ y el 9-12-1705 Antonio de Contreras, vecino de la villa de Rabanera de la Sierra, residente en Toledo, manifestó haber recibido de Juan Tomás de Goyeneche 190.044 mrs. por el importe de 2.639,5 arrobas de carbón, que entregó en las bujerías de la real Casa por cuenta de la provisión de un año que empezó el 1-7-1704 y cumplió el 30-6-1705, a precio de 18/4 la arroba, libres para el otorgante, quedando el pago de derechos reales de la entrada por parte de la Casa de la reina viuda ${ }^{71}$.

Si importante era la provisión de los productos señalados, no menos lo era la de la paja y cebada para la manutención de la caballeriza de la reina viuda. Así, muy poco tiempo después de instalarse en el alcázar, exactamente el 17-3-1701, don Manuel Monter y Aguilar, caballero de la Orden de Santiago y furrier mayor de las caballerizas de la reina, contrató con Diego Sánchez Tamayo, escribano del número, y Pedro de Molina, mercader, ambos vecinos de Toledo, juntos y de mancomún, la entrega de 2.000 fanegas de cebada al precio de $11 \mathrm{rs}$./fanega. Ambos exigieron las preeminencias y exenciones de los proveedores reales ${ }^{72}$. El mismo personaje, por orden del caballerizo mayor y gobernador de la casa real, el duque de Monteleón, ajustó el 15 de agosto con Pedro de Molina Palacios, fiado por Diego Sánchez Tamayo, ambos vecinos de Toledo, el aprovisionamiento de cebada y paja a la caballeriza de la reina desde el 1 de agosto, que la empezaron a proveer, hasta el 31 de julio de 1702, al precio de $10 \mathrm{rs}$./fanega de cebada y $40 \mathrm{mrs}$./arroba de paja, entregándolas en los reales alcázares. Ambos géneros estarían libres de pago de derechos de puertas y puentes en Toledo ${ }^{73}$ El 16-9-1702, Diego Sánchez Tamayo escrituró con Juan Hurtubia, ayuda de furriel de la real caballeriza de la reina viuda, por ausencia de don Manuel Monter, y con orden que aseguró tener del duque de Linares, caballerizo mayor de la reina viuda, la provisión desde el 1 de septiembre, fecha en que comenzó a traer los géneros, hasta el 31 de julio del siguiente año, 7.000 fanegas de cebada y 24.000 arrobas de paja a precio de $12 \mathrm{rs}$./fanega de cebada y $48 \mathrm{mrs}$./arroba de paja, con las condiciones siguientes ${ }^{74}$ :

-La entrega se haría en los alcázares

-Si sobre la calidad de ambos géneros hubiese discrepancias, se había de nombrar personas que lo entendiesen, sin que se le pudiera pedir al dicho Diego otra cosa alguna.

-La cuenta se ajustaría cada mes y se le había de pagar al contado.

-Los géneros no pagarían derechos reales algunos y si tuvieran que abonarlos serían por cuenta de S.M. la reina y se había de dar orden en las puertas y

\footnotetext{
${ }^{70}$ A.H.P.T., prot. 563, fol. 497

${ }^{71}$ Ibidem, fol. 599

${ }^{72}$ A.H.P.T., prot. 562, fol. 55

${ }^{73}$ Ibidem, fol. 186

${ }^{74}$ Ibidem, fol. 735
} 
puentes de Toledo para que pudiesen entrar sin impedimento alguno y si se le embarazare se le había de sacar a paz y a salvo, libre e indemne.

-La libranza para pagarle había de ser independiente de otras, sin que se mezclase con otros caudales.

-Por cuenta de lo que se le estaba debiendo de la provisión que empezó el 1-8-1701 y cumplió el 31-7-1702, se le habían de dar al final de septiembre 32.300 rs. y la restante cantidad se le había de ir pagando puntualmente.

Los mismos personajes anteriores formalizaron el 9-8-1703 que Diego traería desde el día 1 de agosto, hasta el 31-7-1704, cada mes que tuviese 31 días, 475 fanegas y 3 cuartillas de cebada y 2.681,5 arrobas de paja y los que tuviesen 30 días, 460 fanegas y 7 celemines de cebada y 2.595 arrobas de paja al precio de 9,5 rs./fanega de cebada y $42 \mathrm{mrs}$.arroba de paja. Las condiciones eran como en el acuerdo anterior, pero ahora se especificaba además, que la paja debía ser de cebada de pelazga (paja de cebada machacada con cilindros de piedra en vez de trillos, para que resulte larga y hebrosa) y de todo lo que se le estaba debiendo a Diego desde 1-1-1703 y de lo que importaba esta nueva provisión, se le habían de entregar 18.000 rs. Otorgó carta de pago de recibir dicha cantidad de Juan de Hurtubia, mas se especifica que este dinero sólo se deduciría de los dos últimos meses de la nueva provisión, no descontándole ningún maravedí en las mesadas antecedentes ${ }^{75}$.

Al terminar el contrato anterior, don Manuel de Monter ultimó un acuerdo el 5-8-1704 con Sebastián de Huecas y Juan Calvo Huecas, fiados por Francisco Calvo Huecas y Francisco de Prado, todos vecinos de Magán, para la provisión de cebada y paja. Desde el 1 de septiembre hasta el 31-7-1705, entregarían 5.000 fanegas de cebada (200 o 300 más o menos) y de 26.000 a 28.000 arrobas de paja. Los precios convenidos fueron: la fanega de cebada a 8,5 rs y la arroba de paja a 1 real. Además de las condiciones consabidas de poner los géneros en el alcázar y no pagar derecho alguno, se estipulan otras como que se entregará a los otorgantes un anticipo de 24.000 rs., que se irían descontando de la mitad del importe de cada mesada, pero siéndoles pagada en su totalidad la otra mitad; y que recibirían una adehala de 360 rs. Mas enterado Diego Sánchez Tamayo, ofreció servir la misma cantidad de ambos productos a $8 \mathrm{rs}$./fanega de cebada y $32 \mathrm{mrs}$./arroba de paja más 1.000 rs. de aumento en el precio total y la aceptación de las mismas cláusulas. Y no mejorando los maganceños la oferta, se anuló el anterior contrato y se realizó este otro el 6 de septiembre por once meses que empezarían a contar desde el 1 de dicho mes $^{76}$. Vuelve Diego Sánchez Tamayo a ajustar el 20-7-1705 con don Manuel de Monter el avituallamiento de paja y cebada desde el 1 de agosto, por un año. El precio convenido fue de $7 \mathrm{rs}$./fanega de cebada y $32 \mathrm{mrs}$./arroba de paja, con las condiciones consabidas más la de recibir Diego 9.850 rs. que se le estaban debiendo

\footnotetext{
${ }^{75}$ A.H.P.T., prot. 3936, fol. 256

${ }^{76}$ Ibidem, fols. 758 y 792 respectivamente
} 
de las provisiones que tenía hechas en la caballerizas en los años pasados de 1703 hasta fin de julio de $1704^{77}$.

Sobre el vino sólo disponemos de un contrato, el que se realizó el 22-11-1702 con José García de la Plaza, fiado por Fernando de Olarte y Zorita, ambos vecinos de Esquivias, quien se obligó a la provisión del vino que fuere necesario para la real Casa durante el discurso de 13 meses y 20 días que dieron principio el 11 de ese mes y cumplirían el 31-12-1703. El vino había de ser legítimo de Esquivias, claro, de toda bondad, a 16 rs./arroba, libres de derechos, pues estos deberían ser abonados por la real Casa. Recibiría 2.000 rs. anticipadamente para que pudiera comprar vino añejo y después, cada dos meses cumplidos, se le ajustaría la cuenta y se le pagaría lo entregado, continuando de este modo hasta finalizar la obligación ${ }^{78}$. Sin embargo, el abasto de vino continuó mes a mes durante todo el tiempo que doña Mariana se mantuvo en Toledo, como así lo atestiguan los distintos apuntes que quedan asentados en los libros de actas capitulares del Ayuntamiento. Desde el 3 de febrero al 31 de diciembre de 1701 entraron para la Casa de doña Mariana 1.133 arrobas; en el año 1702 fueron 1.017 arrobas; en el de 1703 entraron 918 arrobas; durante el de 1704 se consumieron 1.344 arrobas; en el de 1705 fueron 1.564,5 arrobas y en el 1706, hasta su salida de Toledo en agosto, 486 arrobas $^{79}$.

Además de los artículos antedichos, también quedan reflejados en los documentos de cartas de pago o de contratación que se conservan en el A.H.P.T. otros no menos importantes para cubrir las necesidades de la Casa de la reina viuda en el alcázar. Así tenemos el abastecimiento de nieve, al cual se obligó el 18-2-1701 Gabriel García de Guadalupe, fiado por Juan de Beizama, ambos vecinos de Toledo. El contrato es sólo por un año a partir del 1 de marzo y cobraría por cada arroba 200 mrs. ${ }^{80}$

Ana Constanza Martínez de Rocoux, viuda del sumiller de la real panetería que fue jefe de la confitería de la reina viuda, Juan Gutiérrez de Alarcón, el 29-5-1702 recibió 2.203.983 mrs. de Juan Tomás de Goyeneche. De ellos 252.597 mrs. por lo que importó el gasto de ensaladas, queso, aceitunas y otros productos menores que se necesitaron en dicho oficio de la panetería, desde 2-2-1701 hasta 3-12-1701; el resto por lo que se le debía de nómina ${ }^{81}$.

El guardamangier era el encargado de abastecer a la Casa de doña Mariana de aves, caza menor, carneros, lechones, terneras, corderos y productos derivados de las matanzas (tocino, chorizos, morcillas...), así como de pescados frescos, secos, en escabeche, tanto de mar como de agua dulce. El 31-7-1703, el guardamangier Ambrosio Ibáñez de Isaba, se ofreció y obligó a ser él nuevamente quien aprovisionase la Casa de Mariana de Neoburgo de todos los géneros pertenecientes a su cargo. Las condiciones que impuso son ${ }^{82}$ :

\footnotetext{
${ }^{77}$ A.H.P.T., prot. 563, fol. 179

${ }^{78}$ A.H.P.T., prot. 562, fol. 823

${ }^{79}$ AM.T., libros de actas capitulares de los años 1701 a 1706. Hay meses en los que no se da conocimiento de la entrada de vino para la casa de la reina viuda, por lo que las cantidades pueden quedar incompletas en alguno de los años.

${ }^{80}$ A.H.P.T., prot. 562, fol. 24

${ }^{81}$ Ibidem, fol. 605

${ }^{82}$ A.H.P.T., prot. 3936, fol. 252
} 
-Para hacer acopio de tocino, manteca y otros géneros para el año y satisfacer a las personas que le habían asistido con sus caudales para mantener dicha provisión y a quien contribuía con algunos intereses, se le habían de adelantar 16.500 rs. a cuenta de los 58.819 rs. que se le estaban debiendo de las provisiones hechas hasta el 31-12-1702.

-Se le había de ajustar cuenta y pago a fin de cada mes de lo que importasen los nuevos géneros entregados

-Para conducir a Toledo las terneras, tocino ordinario y de Garrobillas, pescados frescos y salados y escabeches, se le habían de dar las puertas libres sin que los arrendadores de ellas le llevasen derechos algunos ni de los que entrare ni de los que comprase dentro de la ciudad para el servicio de S.M.

-Los jarretes y entradas de tocinos de Garrobillas y desperdicios de terneras se le habían de abonar como se estilaba en las Casas reales hasta el momento.

-Estas condiciones y contrato se habían de entender sólo hasta el día del fallecimiento del otorgante, sin obligación de hacerlas cumplir a su mujer e hijos.

En otras ocasiones no se especifican los géneros de las compras, sino que solamente se dice "diferentes mercaderías". Así se apunta en las cartas de pago que el mercader toledano Lucas del Castillo, firmó haber recibido de Juan Tomás de Goyeneche: el día 24-10-1701 por valor de 1.764 .556 mrs.; el 21-2-1702 por 292.084 mrs. y el 10-7-1704, por 20-.797 rs. y 13 mrs. ${ }^{83}$

Entre otros mercaderes que se favorecían con la estancia de la reina Mariana de Neoburgo en Toledo estaban los pertenecientes al gremio del textil. El 9-7-1701 Pedro Fernández, vecino de Toledo, otorgó carta de pago de haber recibido de don Juan Tomás de Goyeneche, 2.000 rs. (68.000 mrs.) para pagarle un dosel de damasco carmesí, un frontal y una casulla que había entregado para el oratorio de las damas de doña Mariana ${ }^{84}$. El 18 de agosto Pedro Martín del Pulgar, mercader vecino de Toledo, confesó haber recibido del mismo tesorero, 2.165 rs. y 8 mrs. (63.618 mrs.) por diferentes mercadurías sacadas de su tienda para dos casullas, dos frontales, dos albas y otros adminículos de ornamentos, igualmente para el oratorio de las damas ${ }^{85}$.

El 24 de septiembre Lucas del Castillo recibió 3.612 rs. (122.808 mrs.) por diversos géneros de su tienda para los tres vestidos que de orden de S.M. se hicieron y dieron a ciertas personas ${ }^{86}$. El 19-5-1702 el mercader y vecino de Toledo, Eugenio Serrano, dio carta de pago de haber recibido en mano, del tesorero de la reina viuda, 524 rs. por doce varas de damasco morado y carmesí, galón y otros encargos que entregó

\footnotetext{
${ }^{83}$ A.H.P.T., prot. 562, fols. 270 y 458 y prot. 563, fol. 750

${ }^{84}$ A.H.P.T., prot. 562 , , fol. 158

${ }^{85}$ Ibidem, fol. 188

${ }^{86}$ Ibidem, fol. 244
} 
para tres paños de atriles que doña Mariana donaba al convento de capuchinas de Toledo, para cantar la pasión del Domingo de Ramos y oficios de Semana Santa de ese año, a cuyos actos litúrgicos asistió ${ }^{87}$. Por su parte, Eugenio de Orgaz, asimismo mercader y vecino de Toledo, firmó carta de pago el 2 de junio de haber recibido de Juan Tomás de Goyeneche 38.734 mrs. (1.139 rs. y 8 mrs.) por el importe de recados y géneros de su tienda para dos vestidos que dio de orden de S.M. a Margarita, que sirvió por mozo de caballos en la real caballeriza y a un pobre que halló una sortija encendiendo los braseros en los corredores del real alcázar ${ }^{88}$ y el 18-6-.1704 este mismo mercader cobró por el importe del lienzo que entregó para paños y sabanillas de las cocinas y oficios y otras cosas que se ofrecieron durante todo el año anterior, $42.500 \mathrm{mrs}^{.89}$

No solamente se beneficiaban de la estancia de la reina Mariana de Neoburgo en Toledo los mercaderes, tratantes y labradores, sino también algunos artesanos. Así tenemos que el 24-12-1701 el platero, y vecino de Toledo, Juan de Sarauta Zapata, cobró 180 rs (6.120 mrs.) por una caja de plata, sobredorada por dentro y por fuera, que hizo para el servicio del Santísimo Sacramento de la reina ${ }^{90}$ y el 31-3-1702 Juan de Cavanillas, asimismo platero y vecino de Toledo, confesó haber recibido de Juan Tomás de Goyeneche 3.884 rs. (132.056 mrs.) por el importe de algunas piezas de plata pequeñas que había hecho nuevas y aderezos en otras para el servicio de S.M., por cuenta liquidada hasta el 31-12-1701. Este mismo platero firmó carta de pago el 12-4-1703 por valor de 2.950 rs. (100.300 mrs.) que por real cédula de 31 de marzo se le mandaron librar por la Guardajoyas de la reina, por el coste de algunas alhajas, reparaciones de ellas y otras cosas que ejecutó el año anterior ${ }^{91}$ y el 16-6-1704, confesó haber recibido del tesorero de doña Mariana $26.962 \mathrm{mrs}$. por el importe de diferentes aderezos en alguna piezas de plata que ejecutó durante el año $1703^{92}$. El maestro calderero Manuel Carrera y el maestro herrero Diego de Carmena, vecinos de Toledo, firmaron carta de pago el 13-3-1702 de haber recibido de Juan Tomás de Goyeneche $5.450 \mathrm{rs}$. y $25 \mathrm{mrs}$. (185.325 mrs.) por diferentes obras y reparaciones que cada uno ha ejecutado de su oficio para el real servicio, oficios y cocinas de doña Mariana hasta el 31-12-170193 y el 11 de octubre, el primero reconoció haber recibido del tesorero de la reina viuda 3.000 rs. (102.000 mrs.) por las herramientas de cobre y hierro nuevas que había ejecutado para las reales cocinas, arreglos de otras y más extraordinarios precisos en ese año ${ }^{94}$. Este mismo maestro calderero otorgó carta de pago por valor de $967 \mathrm{rs}$. (32.878 mrs.) por el importe de las herramientas de cobre y hierro que ejecutó y reparó para las cocinas de S.M. y demás extraordinarios precisos durante todo el año $1703^{95}$.

\footnotetext{
${ }^{87}$ Ibidem, fol. 578

${ }^{88}$ Ibidem, fol. 610

${ }^{89}$ A.H.P.T., prot. 3936, fol. 735

${ }^{90}$ A.H.P.T., prot. 562, fol. 347

${ }^{91}$ A.H.P.T., prot. 3936, fol. 124

${ }^{92}$ Ibidem, fol. 727

${ }^{93}$ A.H.P.T., prot. 562, fol. 484

${ }^{94}$ Ibidem, fol. 779

${ }^{95}$ A.H.P.T., prot. 3936, fol. 863
} 
Algo singular y que nos proporciona la idea de la escasez y mala calidad del agua de Toledo es la contratación que se le hizo a Eugenio de Benavente, vecino de Getafe pero residente en Toledo, para que trajera agua de El Escorial y otros géneros de Madrid, necesarios a los oficios de la Casa de la reina viuda. Por el servicio desde el 1 de mayo al 31-12-1701, a razón de 13 rs./día y 100 rs. por dos acémilas con las que realizó las mandas de traer diversas colaciones, se le pagaron 3.285 rs. $(111.690 \mathrm{mrs} .)^{96}$

Mientras los proveedores se lucraban al no abonar los derechos reales y municipales de puertas y puentes por los géneros que traían para la Casa de Mariana de Neoburgo, el Ayuntamiento sólo percibía luces y sombras. Los gastos derivados de la estancia de la reina viuda en la ciudad eran cuantiosos y con un continuo goteo. Estaban los pertenecientes a la reparación del alcázar; limpieza y arreglo de caminos y calles, tanto a su llegada como a la de Felipe V cuando vino a visitarla ${ }^{97}$; los que acarreaban las visitas continuas que aquella recibía y a las que atendía la corporación, así como las numerosas asistencias al alcázar para interesarse por la salud de la reina, comunicaciones y besamanos con muy diversos motivos (su cumpleaños, el de la reina María Luisa, el de Felipe V, el del rey de Francia, el día de Santa Ana, el de San Felipe, el de San Luis, felicitar las fiestas navideñas...); tanto llegó a suponer que en el ayuntamiento de 7-9-1703 se acordó que, al estar las arcas de la corporación exhaustas, de esta fecha en adelante sólo se podrían utilizar dos coches, uno para los caballeros comisionados y en el que también iría el secretario mayor y otro para los capellanes, mayordomo y contadores ${ }^{98}$. A esto había que añadir el perjuicio que le ocasionaba a la ciudad el acuerdo a que llegó con la Casa de doña Mariana sobre lo que debía pagar en concepto de derechos reales y municipales por el consumo de los diversos productos que entraban en ella. Se ajustó que abonase la mitad de dichos derechos, así en el vino, donde el Ayuntamiento cobraba 72 mrs. por arroba, la Casa de la reina abonaría solamente 36 mrs.; en el azúcar 3 rs. y por cada cabeza de ganado de cerda 2 rs. ${ }^{99}$; no obstante pagaba tarde mal y nunca.

En marzo de 1703 la Casa de la reina viuda realizó una serie de pagos de arbitrios y sisas municipales así como de alcabalas y cientos y servicios de millones. El día 27 se abonó a Jerónimo López de Escalona, depositario de los arbitrios y sisas municipales, 2.326 rs. y 8 mrs por el consumo que tuvo la real Casa de la reina viuda del vino y tocino; 816 rs. por 272 arrobas y 4 libras de azúcar y el día 31, 200 rs. por 100 canales de tocino, todo ello consumido desde el 2-2-1701 hasta 31-7-1702 ${ }^{100}$. El día 28 pagó a Lorenzo del Val y Heredia, recaudador general de las rentas de las reales alcabalas y cientos de Toledo, 1.400 rs. por derechos de la cebada, paja y verde que consumió el ganado de la real caballeriza de doña Mariana y entró Pedro de

${ }^{96}$ A.H.P.T., prot. 562 , fol. 537

${ }^{97}$ Se llegaron a emplear 818 rs, y 7 mrs. en retranquear la pared de una casa en una calle que iba a la plaza de San Justo para ensancharla de manera que pudiera pasar el coche de la reina cuando fuese a hacer oración a la iglesia, A.M.T., Libro de Actas Capitulares de 1705, $\mathrm{n}^{\circ}$ 126, ayuntamiento de 1610-1705

${ }^{98}$ A.M.T., libro de actas capitulares de $1703, \mathrm{n}^{\mathrm{o}} 124$

${ }^{99}$ A.M.T., libro de actas capitulares de $1702, \mathrm{n}^{\mathrm{o}} 123$, ayuntamiento de 12 de julio

${ }^{100}$ A.H.P.T., prot. 3936, fols. 97, 98 y 108 
Molina, como proveedor de ella, desde 1-8-1701 hasta 31-7-1702 y 4.400 rs. por razón de lo adeudado en las especies y géneros que contribuyen a ellas y entraron para el gasto de la Casa real desde 2-2-1701 a 31-7-1702 ${ }^{101}$. También el día 28 pagó a Eugenia Lucía de Soto, mujer que fue de Juan de Ocampo Cencerrado, vecino de Toledo a cuyo cargo estuvo la renta del gasto de esta ciudad, como heredera universal de su marido, 1.000 rs. por razón de los derechos adeudados por el carbón, caza y leña que entró para el gasto de la Casa de la reina viuda desde el 2-2-1701 a 31-7-1702 $2^{102} \mathrm{y}$, por último, el día 30 entregó a don Pedro de Soto, administrador mayor de la renta de los reales servicios de millones de Toledo y su partido, 2.674 rs por los derechos adeudados por el vino y tocino entrados en el mismo período de tiempo ${ }^{103}$

No hemos hallado ningún otro documento de pago de arbitrios y alcabalas y no debe haberle, porque en el año 1705 se seguían las diligencias oportunas por el Ayuntamiento de la capital tocantes a lo que estaba debiendo de las entradas de vino y demás géneros la Casa de la reina viuda. El regidor Melchor de Cisneros escribió una carta a Juan Manuel de Castañeda, secretario del mayordomo mayor de doña Mariana, instándole al pago de las cantidades adeudadas. Este contestó que estaba en los ánimos del mayordomo mayor saldar las deudas, pero que los empeños de la Casa eran grandes y las asistencias cortas; no obstante, quedaba al cuidado de que se daría satisfacción cuando hubiese caudal para poderlo hacer. A la vista de lo antecedente, el Ayuntamiento acordó que el mencionado regidor continuase las instancias y realizase un memorial para enviárselo a doña Mariana, suplicando que abonase lo que estaba debiendo para poder pagar a los acreedores de los arbitrios y sisas municipales. En este memorial, el Ayuntamiento expone que la ciudad se avino, sacrificándose a cobrar la mitad en los derechos municipales; que los proveedores se estaban beneficiando pues aprovechaban para aumentar en exceso las entradas de los abastos con el pretexto del consumo de la Casa real, cuando éste no era mayor que cuando se tomó el acuerdo; que ya llevaba dos años y medio suspendida la paga de lo que se adeudaba y la ciudad debía pagar a los acreedores que tenían créditos en estos derechos. Todo lo cual, creía que eran motivos suficientes y justos para que S.M. se dignase atenderlos y aclara al final que la ciudad sólo era administradora y no dueña de sus caudales, pues si así fuese no dudaría en ponerlos al servicio de S.M. ${ }^{104}$. El 19 de junio y el 11 de septiembre de 1705 y el 16 de junio de 1706 el Ayuntamiento continuaba intentando cobrar los derechos de arbitrios y sisas que seguía debiendo la Casa de Mariana de Neoburgo ${ }^{105}$.

\footnotetext{
${ }^{101}$ Ibidem, fols. 100 y 101

102 Ibidem, fol. 102

${ }^{103}$ Ibidem, fol. 107

${ }^{104}$ A.M.T., libro de actas capitulares de 1705, $\mathrm{n}^{\circ} 126$, ayuntamientos de 13, 16 y 27 de marzo

${ }^{105}$ A.M.T., ayuntamientos respectivos en los libros de actas capitulares no 126 y 127.
} 


\section{Conclusión}

La "estancia obligatoria" de doña Mariana de Neoburgo en Toledo no le trajo a la ciudad beneficio económico alguno, si como tal consideramos los derechos de puertas por los que tributaban los productos que entraban para su casa en el alcázar, pues se le redujeron en un $50 \%$, los pagaba "tarde mal y nunca" y los proveedores se aprovechaban introduciendo más cantidad de los artículos declarados para las necesidades de la reina viuda para venderlos a otros consumidores, con lo que defraudaban al Ayuntamiento en casi la misma cantidad de la que este podía beneficiarse. Por el contrario le produjo más gastos protocolarios y de reparaciones innecesarios.

En cuanto al aspecto social tampoco se vio favorecida en nada. La reina viuda acarreó un trastorno en la cotidianeidad y rutina de las costumbres del cabildo catedralicio y del Ayuntamiento. Ambos organismos tuvieron que atender sus deseos y los actos de protocolo oportunos que les distrajeron en demasía, además de ocasionar, como dijimos, unos gastos innecesarios al Consistorio en sus paupérrimas arcas. En el político hizo aflorar dudas en algunos personajes y una confusión mental en otros. No es posible asegurarlo tajantemente, pero tampoco es nada descabellada la hipótesis de que practicó la política de dispensación de cargos y honores a ciertas autoridades de la capital para contar con su ayuda y que en su momento la asistiesen en sus propósitos y trató de nadar entre dos aguas ${ }^{106}$, acompañada del cauto y astuto arzobispo de Toledo, el cardenal Portocarrero, excepto cuando creyó que era irreversible el triunfo del pretendiente austracista, entonces abrió su espíritu y manifestó públicamente su posición.

${ }^{106}$ Ya había actuado de esta manera tras la muerte de Carlos II, al pretender servir de introductora en España de Felipe V a la vez que escribía a su hermano el Elector Palatino manifestándole sus trabajos a favor de la causa e intereses del Emperador, al que mantenía su inquebrantable fidelidad. A. DE BAVIERA, op. cit. (nota 2), p. 310 